[8] Koster, R. W., Baubin, M. A., Bossaert, L. L., Caballero, A., Cassan, P., Castrén, M. et. al. (2010). European Resuscitation Council Guidelines for Resuscitation 2010 Section 2. Adult basic life support and use of automated external defibrillators. Resuscitation, 81 (10), 1277-1292. doi: 10.1016/j.resuscitation.2010.08.009

[9] Lateef, F. (2010). Simulation-based learning: Just like the real thing. Journal of Emergencies, Trauma, and Shock, 3 (4), 348-352. doi: 10.4103/0974-2700.70743

[10] Peyton, J. W. (1998). Teaching and Learning in Medical Practice. Heronsgate, Rickmansworth: Manticore Europe Ltd, 256.

[11] Krautter, M., Weyrich, P., Schultz, J.-H., Buss, S. J., Maatouk, I., Junger, J., Nikendei, C. (2011) Effects of Peyton's Four-Step Approach on Objective Performance Measures in Technical Skills Training: A Controlled Trial. Teaching and Learning in Medicine, 23 (3), 244-250. doi: 10.1080/ 10401334.2011.586917

[12] Mandhane, N., Ansari, S., Shaikh, T., Deolekar, S. (2015). Positive feedback: a tool for quality education in field of medicine. International Journal of Research in Medical Sciences, 1868-1873. doi: 10.18203/2320-6012.ijrms20150293

[13] Qureshi, N. S. (2017). Giving effective feedback in medical education. The Obstetrician \& Gynaecologist, 19 (3), 243-248. doi: 10.1111/tog.12391

[14] Glantz, S. A. (2012). Primer of biostatistics. McGraw Hill Professional, 459.

[15] Davis, C. S. (2002). Statistical methods of the analysis of repeated measurements. New York: Springer, 744.

[16] Scott, I., Mazhindu, D. (2014). Statistics for Healthcare Professionals: An Introduction. SAGE Publications Ltd, 256.

[17] Munster, T., Stosch, C., Hindrichs, N., Franklin, J., Matthes, J. (2016). Peyton's 4-Steps-Approach in comparison: Medium-term effects on learning external chest compression - a pilot study. GMS Journal for Medical Education, 33 (4). doi: 10.3205/zma001059

\title{
HISTORICAL AND CULTURAL APPROACH TO THE PROCESS OF STUDYING OF GENERAL PEDAGOGICAL DISCIPLINES
}

\author{
Eugene Prokofiev \\ Department of Psychology and Pedagogy \\ National University of Physical Education and Sports of Ukraine \\ 1 Fizkultury str., Kyiv, Ukraine, 03680 \\ e.prokofiev@bigmir.net
}

\begin{abstract}
The article analyzes the historical and cultural approach to the implementation of the principle of historicism to resolve the educational and breeding problems. It defined the components, which forms the methodological culture taking into account the innovative ideas and values from the past periods of educational thought development in Ukraine. It proved the necessity of connection between the history of pedagogical science and the real problems of theory and practice of pedagogy nowadays.

Modern pedagogical university should propose a scheme for not only the assimilation and use of knowledge already in the process of learning and teaching practices, their understanding of the unity of disciplines. The need for integrating forms of knowledge, its use and problem are caused by the restructuring of higher education. The idea of dismantling the higher education standards in the global market for the college can be realized through the idea of pedagogical universities. This idea foresaw the changes to increase the array of general knowledge along with professional. Integrating knowledge will facilitate distribution of creative material for individual schemes modeled not for his/her learning, but in order to the use of variant.

A current teacher has a high level of not only professional, but also general training. General education does not mean "omni-science", and the whole thinking capability that covers the relationship of individual branches of knowledge. A teacher integrates
\end{abstract}


various fields of scientific knowledge at practical actions to understand him/herself and to teach students to solve economic and social problems.

Keywords: methodological culture, pedagogy science development, historical analysis, linkage of periods, methodology, stages, progress.

\section{Introduction}

The cultural society consists of people who meet the criteria of the most perfect model of the social order. Theoretically, each society hopes that school will help, believing that a teacher has to meet the criteria of the predictable model, transfer the experience, creating new models among his/her students. Everyone is a human of culture, his or her specific culture that varies in time and space. But not all people are guides of that culture. We should not forget, that since the first models of cultural human (Confucian and Platonic models), a long and goal-oriented learning has been included. Today we refer the education system to the sector, where they teach, or someone studies, acquiring knowledge through self-education. Such sciences as pedagogy, history, ethnography, anthropology, etc. show that during the era of primitive society the concept of education was considered as a collective transmission of a holistic lifestyle and reproduction of it in the transmission process from generation to generation.

The analysis of historical and educational researches [1] about the questions of studying of general pedagogical disciplines revealed the components, which form a system of knowledge of the realization of principle of historicism, which nowadays can affect the general scientific level of qualification of future teachers.

Historical and cultural approach to solving education and upbringing problems is one of the fundamental ones, which requires considering the process, as well as any other phenomenon, in motion, dynamics, development, in linkage with the specific social conditions. To implement the principle of historicism means to consider the trends of development, to be able to see the origins of the future trends in the existing object or phenomenon. Only synthesized and summarized in the relevant theoretical concepts and principles, the historical experience is a prerequisite for the modern scientific research. Besides, any productive effect on an individual and society must meet the requirements of time; take into account the level of development of an individual and the level of culture of the whole nation. So the principle of culture relevance should also be incorporated into the content of studying general pedagogical subjects. That implies a systematic updating of forms and methods of educational performance, synthesizing with different aspects of culture, which characterize the highest level of excellence.

The historical-cultural approach gives the opportunity to model the system of studying general pedagogical subjects, coordinating it with the features of the environmental development, where the system is the leading active component of interaction, besides to follow the principle of hierarchy, which provides an appropriate ordering of the integrated system and gives an opportunity to consider each component of the system (subsystem) as an equitable system. It means that the historical and cultural approach is one of the mechanisms of constructing a system of teaching of general pedagogical disciplines, providing, along with other approaches and principles, a systematic approach to the process of general pedagogical training.

\section{Aim of research}

To determine characteristics of the components in the process of formation of a culture of a specialist, taking into consideration innovative ideas and values from the pas periods of educational thought in Ukraine. To prove the necessity of connection between the history of pedagogical science and the real problems of theory and practice of pedagogy nowadays.

\section{Materials and Methods}

The culture of specialists can be characterized as an expression of maturity and development of the whole system of socially significant personal qualities, which are efficiently implement- 
ed in individual activities (social, political, professional, research, communication etc.). It is the result of the quality of knowledge, interests, beliefs, norms and behavior, skills and social emotions.

1. The system of knowledge and outlook of the individual forms are formed on the broad knowledge of the basis of the information (the indicator serves as a thesaurus of active personality conceptual stock). Horizon, erudition developing of personality in the cognitive functions and related intellectual activity.

2. The system forms the ideological convictions, cultural level of an individual, which is formed on the basis of interests, values and life choices in the process of axiological reflection, self-regulation. His/her ideological position is an indicator of personality. Beliefs implemented in the ideological activity that serves as the ideological basis of all forms of activity.

3. The system of developed skills and abilities is based on these standard forms of practice, which is formed on the basis of social needs and attitudes in the process of accumulation and implementation experience. They are an indicator of productivity of activity.

4. The system of individual standards of behavior and learning methods of forms of the level of regulation of social behavior of an individual, which is formed on the basis of principles and cultural patterns of conduct through various forms of communication to popularize self. They are manifested in behavior and creative activity of personality.

5. The system of social feelings forms a level of emotional culture that is formed on the basis of experience of the processes and behavior of the individual, which is implemented in emotional activity.

So culture as an integrated indicator of creativity of behavior and activity comprises all components together in unity and interaction. For example, thesaurus outlook of personality characterizes its fullness in cognitive, intellectual potentials. The range of interests provides a level of spiritual needs. Ideology determines the social orientation of personal culture [1, p. 14-15].

Skills and abilities form the subject-breadth of practical and theoretical experience of an individual. Accepted individual rules and learned methods of regulating the behavior and actions. Culture feelings that characterize the development of humanistic orientation and emotional sphere of personality, emotional saturation determines its behavior and activity.

Culture is the social world examples of behavior and activity. Already the "Instructions of Merikara" the memo of Egyptian writing of III. B.C. say: «Follow your "of your fathers and their ancestors [2, p. 153]. Even famous in all attractions followed someone. Understanding the culture and respect of cultural rights have come through a long trial. Today, some are returning to the model of "cultural expert" or other "classical educated" human, the model that enriched the culture of thinking and feeling. Take into account aspects like history, and the history of mankind».

A teacher can be proud that many people, who dedicated themselves to education, understand it not only as a transfer of experience but as the basis of unity of human nature stories, based on planetary unity. The maximalist requirement of Ya. Komenskiy "teach everyone everything about everything" was aimed exactly at that [3, p. 276]. That's why, in reading lecture of kameralistic in Yaroslavskiy lyceum K. Ushinskii found it necessary and possible in the context of education to talk about the geography of "Countries of Dnipro", its people and their national identity, "... the landscape ... reflects the original soul of slavonian. His/her passion, unbridled penchant for farming, his/her calm and slow nature, his/her bright, direct character [3, p. 78].

To imagine the amount of student education as integrity, history of pedagogy with social science disciplines cycle should disclose the problem of social and cultural determination of educational systems, objective conditionality of diversity. Leading regulative modern pedagogical thinking will not appear without this principle of historicism [1, p. 32]. All humanity subjects including pedagogy are designed with the transfer of factual material to educate patriotism. For this they must be seen in historical and cultural context. For example, you consider the history of pre-education, emphasizing the inequality in obtaining the knowledge, limited of educational content orientation of education to the needs of bourgeois society, etc. [1, p. 146].

T. Shevchenko spent his money and published «Bukvar Yuzhnoruskii» and dreamed to create Sunday schools textbooks of mathematics, geography, history, ethnography. From 1888 to 1907 years (before the official recognition of «little Russian adverb» by the tsarist government) the 
known writer B. Hrinchenko illegally taught to read and write by his own the textbook "Ukrainian grammar before reading and writing science".

Currently, young people do not accept the state as a whole, they divides it into separate groups of people and not see progress in integrated strength, and the difference in our lives by living in other countries. The old feeling of patriotism is lost and universal civic patriotism in no hurry to appear. Task cycle of general disciplines is difficult, because the immediate task was the question that social and economic progress in every region of our country is accompanied by progress in the spiritual based on the cultural identity of nations and nationalities living outside their state-territorial entities without more opportunities to implement national-cultural needs in education, communication, folk. In this regard, the study of subjects of general cycle should be built with an emphasis on folk sources in the history education. Moreover, the nation is the source of all representatives of progressive pedagogy.

A teacher required other nations' folk pedagogy as knowledge of the existence of his or her sources and the ability to be their keeper. The need to consider folk pedagogy is in parallel with the development of foreign and national history of Ukrainian pedagogy, its identity, relationship to other cultures of democratic self-government. For a long time the term "people's education" was used in relation to education only in "ancient eastern Slavs" and Kievan Rus. The right of existence of traditional pedagogy as such, its basic concepts was confirmed only in the works of the $30 \mathrm{~s}$, but problems in the field of pedagogy of nationality were set only in the second half of the 50s [4, p. 307].

The way of student knowledge of the structure of formal education and basic literacy of this culture is realized through the ability to pass through the centuries in scientific and theoretical, literary, historical understanding.

It is possible only to conclude that many factors participate in the development of the modern person. Even wider palette is in the process of teacher's development. The challenges of the new thinking, democratization, humanization of schools in new ways are given. In search of new knowledge and morality there is a need of unity and opposition.

Historians are unanimous in assessing the christening of Russ as the phenomenon to spread progressive writing and education, literature, art that based creation of culture of East Slavic peo-ples, but requires a more sophisticated study of the issue of pre-Christian literature, culture, art, Aboriginal or Aboriginal culture that was significantly higher in its development than Christianity. Through the study of the history of education we declare also that monasteries of world religions are the product of medieval Western Europe and became guardians of literacy in general, in part contrary to the idea of their origin. Characteristically, the birth of a "model of cultural rights" was only the beginning of the second millennium, and coincided with the birth of the western educa-tion system from universities to children's institutions. Researchersphilosophers believe that the Christian model of human culture of the middle Ages received its perfection, being represented by university teachers.

Linking literacy, education, religion one should know that in Kievan Russ dwellers of monasteries copied not only preaching, but tried to reflect the history, culture and nature. Interestingly, the relevant question of today heliobiology - the science of sun exposure on the biosphere, was recorded as observations, deep into the stone and parchment, further in the Crypt and the Novgorod chronicles. In the history of Ukraine there were many steps compatible to solution of the problem of education and Christian morality. Publication of "Magisterium Gospel" (collection of sermons on Gospel themes) in the XVI century is for us one of the clearest evidence. But we cannot leave aside the influence of religion on school and education, which it showed, as the main ideology of monarchical state.

After 1917 religion relate to education, depending on the relationship of church and state. The church, which is loyal to the state, advocates peace, associates humanistic endeavors of many people in today's society, promotes assertion of moral qualities of an individual through manifestations of mercy. But the line of ideological orientation of school - is its own. It is necessary to clearly track, learn the history of the school to determine a common humanism, morality and differences in outlook. Many aspects in this study will help to individual teachers who were believers, were able to use the theory and practice of positions of scientific outlook [4, p. 237]. 
It is rightly marked today that conscience, compassion - are the origins of morality for centuries according to themselves in the human world and the religion preached universal human values. Religion says that the source of the rules of morality is God who gives them to people. The scientific point of view suggests that the source of morality is not supernatural powers, but real human relationships. Religion it is a reflection of human life. Practice is the criterion of truth. Religious practice is instructive by both positive and negative examples. You cannot focus on one side of it, you cannot rely on unilateral assessment. The objective approach, alternative assessments - as noted by L. Vovk, promote the use of religious history as a part of the historical and cultural context of historical and pedagogical science and history of education [5, p. 68-72].

Modern pedagogical university should propose a scheme of not only the assimilation and use of knowledge already in the process of learning and teaching practices, but its understanding as the unity of disciplines. The need for integrating forms of knowledge, its use and the problem caused by the restructuring of higher education. The idea of dismantling the higher education standards for the college in the global market can be realized through the idea of pedagogical universities. This idea foresaw the changes to increase the array of general knowledge along with professional. Integrating knowledge will facilitate distribution of creative material for individual schemes modeled not for its learning, but in order to the use of variant.

Without dwelling on the methods of attracting students to integrate knowledge, select one of the important options for the use of content material. A student is not always psychologically ready to absorb all the sciences, the proposed program, but through the integration of the problem that interests him, he is implicitly included in the perception and learning. You can allow for the use of pieces of information, the problems of knowledge and later science in general. The integration combines the knowledge objectives of education and knowledge of life, which focus on the individual. It excludes organic formalism, and provides a specialist personal basis. Try to partially reveal the possibility of integration of knowledge in the study of general disciplines cycle.

Integration requires consideration of concepts and content of education, as the education of early human life was considered as reproduction of life by generations. Initiation into the mysteries of life is the education of primitive people because we studied ethnography, anthropology, etc. If history reveals pedagogic methods in external effects on humans for their improvement, the very idea of human as an end in itself in historical and pedagogical process, real ideas of humanism are revealed in the integration of pedagogy and psychology, the history of philosophy, history, culture.

The historical development of theoretical models of teaching science shows that education like logic, ethics, psychology, derives from the philosophy, which contributed to the birth of pedagogy as a science. Therefore, in the course of history Education is the relationship between philosophy and issues of education and training.

A current teacher has a high level, not only professional, but also one of general training. General education does not mean "omniscience", but the whole thinking capability that covers the relationship of individual branches of knowledge. A teacher integrates various fields of scientific knowledge at practical actions to understand him/herself and to teach students to solve economic and social problems.

Historical and educational science makes it possible to assess the dynamics of the problem of the relationship of the individual, society and nature through the study of the history of educational thought. Modern life requires a special balance in the system, man - society - nature.

The use of the pedagogic heritage of the past helps selects the settings of orientation of human activities in order to preserve the planet, living life. The heritage of A. Makarenko shows the original practice of a child team to transform the environment. It recommends to reach awareness of a link "Logic man - nature", studying the use of nature as a means of seeing the world, the element of ideology [4, p. 238]. Recommendations on the use of the principle of regional Science help a teacher in dealing with environmental education. Historical and pedagogical knowledge can consolidate knowledge on the history and theories of various sciences, and thus contribute to the individual in different directions. Integrating knowledge of different disciplines of history education, a student must provide the ambiguity of the role of religion in society and in education. You can select the period of Baptism, of religion in the Middle Ages, etc. for that. 
A universal indicator of science is the ability to investigate child's well-being, from stars of birth till today. Ethnography, literature, history are subsidiary for historical and pedagogical knowledge. The effectiveness of the integration of knowledge depends on their level of focus on an individual, on its activities.

Assessment of the physical condition of the human thinker of XVI century L. Vives sound simple and affordable through the history of pedagogy (Ya. Komenskii studied his work in the preparation of "Great didactics". He defined "Common sense - a state of the body, which is common sense." Humanism in such integration of pedagogy and psychology, physiology aimed at health care of children [1, p. 41].

\section{Result}

The given characteristics of the current socio-cultural situation must purposefully and consistently coordinate the higher school educational process with the requirements of society. This requires a different stimulation of development of material forces of future teachers, the removal of all obstacles to the disclosure of his/her creative personality (for example excessive teaching and learning activities, mandatory study of a discipline course only under the supervision of the appointed teacher, the inability of individual training programs and hence the lack of training schools to implement true individualization of the educational process, limited choice of majors The important role in the implementation of selected targets and specific is played by a spiritual environment of pedagogical university, as a task that requires a compulsory solution is to create an atmosphere of goodwill, cooperation, mutual educational work; the atmosphere, which contributes to awakening a desire for self-development, self-improvement.

However, any of the actions that will be implemented, cannot be a measure if the object of educational efforts of groups of institutions will not present a student, will not be able to achieve the organic unity of his/her spiritual development and professional development, and the teaching process, organized by the university, will not focus on the education of their general and pedagogical culture.

Speaking about the creative direction of educational preparation for future teachers, we should keep in mind that to "teach creativity in general" is not possible. But you can and should raise the propensity to creative work. It is necessary to form the ideological; intellectual, psychological, aesthetic, moral commitment to creativity. Creative activity involves active self-expression of personality. Increased creativity of a specialist depends on the level of his/her security elements of creativity. Educating students in the creative approach to educational activities in schools involves the formation of the installation, a certain level of assimilation of creative methods and techniques.

But creativity does not occur by itself. A necessary condition of it is a sense of purpose of the planned actions; interest in the process and its final result, the presence of willpower, practical commitment to the goal. The nature and results of the work on forming a creative approach to educational work in students are largely caused by a content of the training material. Elements of creativity of all kinds of work must be present in laboratory studies on methods of upbringing, education. Teachers have to use the information of mastering, conducive to the formation of the students' creative potential of sustainable confidence in the objective necessity of systematic professional pedagogical improvement. The organic relationship of active theoretical and practical training is ultimately translated into creative self-expression and creative activity of the student collective action, that is a major creative individual channels in itself.

In formation of a specialist a large part belongs to historical, educational, general historical training, orientation in the laws of social and educational processes, understanding of world-historical and pedagogical process, the availability of knowledge in the history of national schools, folk pedagogy and advanced educational views, the ability to use the methods of comparative pedagogy, work with sources, ignore facts, analyze them. Studying the history of education becomes further the development model of education, devoid of social and cultural homogeneity.

Effective implementation of the process can be carried out based on conditions that determined: 
1) Creating of problematic situations based on patterns of problem-based learning (mastering process, control knowledge and skills in problem situation):

- define developing goals of discipline, its sections and individual topics;

- perform the logical and problematic analysis of structuring of study;

- conduct psychological and pedagogical analysis of selected issues and identify specific cognitive task (question);

- allocated set of problems are seamlessly logged in training courses (including preparation of the previous in the Content of the course and expenditure of time to study it).

2) Someone who learns must have a high motivation to carry out the actions and methods during problem resolution of tasks. This requires techniques and methods of activation of perception and assimilation of information and independent creative thinking [6, p. 105]. of students:

You must define basic provisions to be observed in the development of the creative potential

- first you have to prove psychological and educational requirements for taking of problematic situations;

- someone who learns must have a high motivation to operate in the problem resolution of tasks;

- the process of formation of creative skills must be in accordance with the theory of "gradual formation of mental actions";

- the most common and effective method of creative learning of most general scientific and general technical disciplines is imitation in certain game situations [7].

Finding of ways to understand human and humanity as a single whole and attempts to coordinate it with his/her education was typical for many progressive educators. Exactly this line is a continuous link of humanistic education and history of education. Tracing the path of understanding the human place in the universe, it is necessary to weigh and value education and understanding of the necessity to educate future generations. It is the assimilation of new thinking through education and training oriented tasks of modern middle, higher and vocational schools, task of education for adults [8].

So, in conclusion in this article it may be noted that in the process of the content general pedagogical education disciplines is important to consider advanced ideas and value characteristic of periods of pedagogical thought in Ukraine. The content of educational material in the discipline should respond to the greatest professional profile that was prepared.

Historical and cultural approach makes it possible to model, streamlining the studying of general disciplines, consistent with the features of the content of educational material, internal disciplinary and interdisciplinary communication and should respond to the greatest professional profile that was prepared [9].

\section{Conclusions}

1. The given characteristics of the current socio-cultural situation must purposefully and consistently coordinate the higher school educational process with the requirements of society.

Speaking about the creative direction of educational preparation for future teachers, we should keep in mind that to "teach creativity in general" is not possible. But you can and should raise the propensity to creative work. But creativity does not occur by itself. A necessary condition of it is a sense of purpose of the planned actions; interest in the process and its final result, the presence of willpower, practical commitment to the goal.

2. In formation of a specialist a large part belongs to historical, educational, general historical training, orientation in the laws of social and educational processes, understanding of world-historical and pedagogical process, the availability of knowledge in the history of national schools, folk pedagogy and advanced educational views, the ability to use the methods of comparative pedagogy, work with sources, ignore facts, analyze them.

3. A current teacher has a high level of not only professional, but also general training. General education does not mean "omniscience", and the whole thinking capability that covers the relationship of individual branches of knowledge. A teacher integrates various fields of scientific 
knowledge at practical actions to understand him/herself and to teach students to solve economic and social problems.

\section{References}

[1] Vovk, L. P. (2012). Istoriya osvity i pedagogiky v zagalniy, metodologichniy i profesiinii kulturi vchitelya: posibnyk - komentar is propedevtyky vyvchennya istorii pedagogiky. Kyiv: Vyd-vo NPU imeni M. P. Dragomanova, 332.

[2] Korostovtseva, M. A.; Korostovtsev, M. A., Katsnelsona, I. S., Kuzischina, V. I. (Eds.) (1980). Hrestomatiya po istorii Drevnego vostoka: Uchebnoe posobie: V $2 \mathrm{ch}$. Ch. 1. Moscow: Vyschaya shkola, 31-36.

[3] Oksa, M. M. (2007). Stratehichnyi menedzhment v osviti. Melitopol: MDPU, 178.

[4] Oksa, M. M. (1997). Vivchennya distsiplin zagalno pedagogichnoyi pidgotovky vchytelya u pedagogichnyh vuzah Ukrayiny (1917-1991 rr.). Kyiv: TOV «Mizhnarodna finansova agentsiya». Bibliograf, 315 .

[5] Vovk, L. P. (2016). Akmeolohichnyi pidkhid do vyvchennia problemy profesiinoho samorozvytku maibutnoho vchytelia. Naukovi zapysky Vinnytskoho derzhavnoho pedahohichnoho universytetu imeni Mykhaila Kotsiubynskoho. Seriia: Pedahohika i psykholohiia, 47, 68-72.

[6] Trotsko, G. V. (Ed.) (2008). Istoriya pedagogiky. Kharkiv, 545.

[7] Prokof'ev, E. G. (2016). Pryncypy metodologichnogo proektuvannya v suchasnij pedagogichnij osviti. Zbirnyk naukovyh prac. Seriya: Pedagogichni nauky. Vipusk LXIX T. 1. Khersonskii derzhavnyi universitet, 52-56.

[8] Prokof'ev, E. G. (2017). International scientific and practical conference "Innovations and modern technology in the education system: contribution of Poland and Ukraine": Conference Proceedings, 21-25.

[9] Prokof'ev, E. G. (2014). Model zahalno pedahohichnoi pidhotovky maibutnikh uchyteliv v umovakh dystantsiinoho navchannia. Mizhnarodnii naukovyi visnyk zbirnyk naukovykh statei za materialamy XXVII Mizhnarodnoi naukovo-praktychnoi konferentsii, Uzhhorod-Budapesht, 26-29 lystopada 2013 roku. Uzhhorod: DVNZ «UzhNU», 8 (27), 183-195.

[10] Palosh, R. (2012). Teorii obucheniya i obrazovatel'nyye posledstviya, vtoroye izdaniye, peresmotrennoye i dobavlennoye izdatel'stvo West University, Timishoara. 